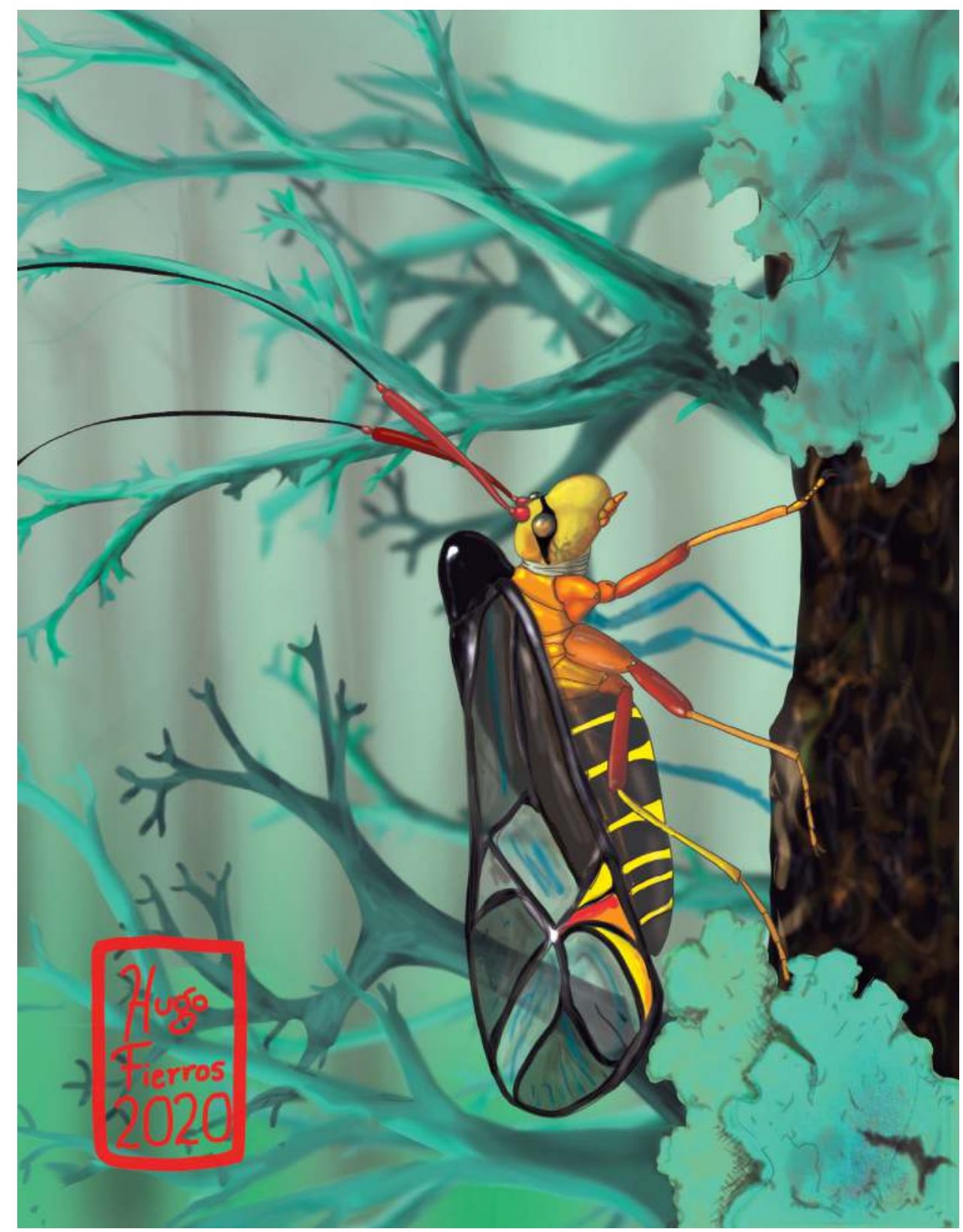

Dugesiana, Año 27, No. 2, julio 2020-diciembre 2020 segundo semestre de 2020), es una publicación semestral, editada por la Universidad de Guadalajara, a través del Centro de Estudios en Zoología, por el Centro Universitario de Ciencias Biológicas y Agropecuarias. Camino Ramón Padilla Sánchez \# 2100, Nextipac, Zapopan, Jalisco, Tel. 37771150 ext. 33218, http://148.202.248.171/dugesiana/index.php/DUG/index, glenusmx@gmail.com. Editor responsable: José Luis Navarrete-Heredia. Reserva de Derechos al Uso Exclusivo 04-2009-062310115100203, ISSN: 2007-9133, otorgados por el Instituto Nacional del Derecho de Autor. Responsable de la última actualización de este número: José Luis Navarrete-Heredia, Editor y Ana Laura González-Hernández, Asistente Editorial. Fecha de la última modificación 1 de julio 2020, con un tiraje de un ejemplar.

Las opiniones expresadas por los autores no necesariamente reflejan la postura del editor de la publicación.

Queda estrictamente prohibida la reproducción total o parcial de los contenidos e imágenes de la publicación sin previa autorización de la Universidad de Guadalajara. 


\title{
The Trichadenotecnum corniculum species group from Thailand (Psocodea: Psocidae)
}

\section{El grupo de especies de Trichadenotecnum corniculum de Tailandia (Psocodea: Psocidae)}

\author{
Kazunori Yoshizawa ${ }^{1} \&$ Charles Lienhard $^{2}$ \\ ${ }^{1}$ Systematic Entomology, School of Agriculture, Hokkaido University, Sapporo 060-8589, Japan; ${ }^{2}$ Geneva Natural \\ History Museum, CP 6434, CH-1211 Geneva 6, Switzerland. Correspondence: K. Yoshizawa (psocid@res.agr. \\ hokudai.ac.jp)
}

\begin{abstract}
Five new species of the corniculum species group of the psocid genus Trichadenotecnum Enderlein, T. alfonsoi, $T$. lingens, T. palmula, T. affinifelix and T. separatum were described from Thailand. These species share a couple of male genital apomorphies with the other Oriental species of this species group recorded from China, Hong Kong, Malaysia, Singapore and Indonesia. The Japanese species of the corniculum group are considered to form a different clade placed as the sister to the rest of Oriental species.
\end{abstract}

Key words: Psocoptera, taxonomy, new species, male genitalia, Oriental region.

\section{RESUMEN}

Se describen cinco especies del grupo de especies corniculum del género de psócidos Trichadenotecnum Enderlein de Tailandia: T. alfonsoi, T. lingens, T. palmula, T. affinifelix and T. separatum. Estas especies comparten un par de apomorfias en el genital masculino con otras especies Orientales de este grupo de especies registradas para China, Hong Kong, Malasia, Singapure e Indonesia. Las especies japonesas del grupo corniculum se consideran que forman un clado diferente ubicado como hermano del resto de las especies Orientales.

Palabras clave: Psocoptera, taxonomía, especie nueva, genitalia masculina, región Oriental.

The corniculum species group of the psocid genus Trichadenotecnum was first proposed by Yoshizawa (2003) for two Japanese species characterized by two male genital autapomorphies: the conical process on the paraproctal trichobothrial field (trichobothrial process) and the denticulate or serrated hypandrial right corner. Subsequently, several species from China, Hong Kong, Malaysia, Singapore and Indonesia were assigned to this group (Yoshizawa \& Lienhard 2004; Yoshizawa et al. 2014). The monophyly of this group and its deep divergence within the genus Trichadenotecnum were suggested by morphological data (Yoshizawa 2003), and later confirmed by extensive molecular phylogenetic analyses (Yoshizawa et al. 2016, 2017).

Through the TIGER project (Thailand Inventory Group for Entomological Research: http://sharkeylab.org/tiger [accessed on Feb 25, 2020]), many psocids (Psocodea: 'Psocoptera'), including about 50 species of the genus Trichadenotecnum, were collected and entrusted to the Geneva Natural History Museum. Of them, the alinguum and the marginatum species groups have already been studied (Yoshizawa \& Lienhard 2015a, b). For this paper, we studied the corniculum species group from the TIGER material.

\section{MATERIALS AND METHODS}

All specimens examined in this study were collected through the TIGER project with Malaise traps; T-numbers are TIGER project sample numbers. The specimens were preserved in $80 \%$ ethanol. Type material will be deposited in the Queen Sirikit Botanical Gardens, Thailand.

As discussed below, all species described in this paper are superficially very similar to each other. Based on mor- phology, male-female association for separately collected specimens could not be established, and there were no samples in which possibly conspecific males and females were collected simultaneously. Therefore, the following descriptions are exclusively based on male specimens.

Abbreviations used in the descriptions: $\mathrm{BL}=$ body length; FW = forewing length; $\mathrm{HW}=$ hindwing length; $\mathrm{IO} / \mathrm{D}=$ shortest distance between compound eyes divided by longitudinal diameter of compound eye in dorsal view of head.

\section{The corniculum group \\ RESULTS}

See Yoshizawa (2003) and Yoshizawa \& Lienhard (2004) for group diagnosis. In addition to the diagnostic characters mentioned by these authors, the following male genital features are present in all species examined here: paraproct with dorsal swelling at base of distal lobe; hypandrial median tongue well developed and thin; hypandrial right lateral corner densely covered by denticles; phallosome bifurcated apically.

\section{Trichadenotecnum alfonsoi Yoshizawa and Lienhard, n. sp. \\ (Figs 1A, 2) \\ http://zoobank.org/6AF52839-A95B-40BB-B79B- 27662D8137DB}

Holotype. Male. THAILAND, Sakon Nakhon, Phu Phan NP, behind forest protection unit at Huay Wien Prai, $17^{\circ} 6.863^{\prime} \mathrm{N} 104^{\circ} 0.327^{\prime} \mathrm{E}, 387 \mathrm{~m}$, Malaise trap, $17-25$. ii.2007, Winlon Kongnara leg. T1692 (Tiger 2). 
Paratypes. 2 males, same locality as holotype, 10-17. ii.2007, Winlon Kongnara leg. T1687 and T1689; 1 male THAILAND, Sakon Nakhon, Phu Phan NP, Nam Hom Waterfall \# Sao Hi, $17^{\circ} 7.34^{\prime} \mathrm{N} 104^{\circ} 0.788^{\prime} \mathrm{E}, 344 \mathrm{~m}$, Malaise trap, 4-10.iii.2007, Sailom Tongboonchai leg. T2368.

Description. Male. Head. Almost uniformly blackish brown, including mouthparts and antennae, except for pair of white spots next to ocellar field, pair of pale regions on frons, and white dorsal region of postclypeus. Eyes black, IO/D 0.8; ocellar field black.

Thorax. Blackish brown except for white membranous region and white longitudinal line in middle of mesoscutum; metascutum with small white spot on posterior end of each scutum lobe.

Legs. Blackish brown.

Forewing. As in Fig. 1A.

Terminalia. Epiproct (Fig. 2AB) with conical lobe anteromedially. Paraproct (Fig. 2A) without trichobothrial process but with wrinkled area medially; with dorsal swelling at base of distal lobe; distal process slender. Hypandrium (Fig. 2C) with well-developed left process; median tongue circular in shape, with week serration on left posterior margin; right corner strongly projecting posterolaterally, with keel-like lateral expansion. Phallosome (Fig. 2D) with pair of simple posterior processes.

Measurements (in mm). BL 1.8-2.1; FW 2.4-2.6; HW $1.8-2.0$

Female. Unknown.

Etymology. The species epithet honors our friend and colleague, Alfonso Neri García Aldrete, for his eminent contributions to the study of psocopterans.

Remarks. This species resembles T. pycnacanthum $(\mathrm{Li}$, 2002) by the epiproctal and hypandrial structures but can be distinguished from it by the smaller body size, lack of the trichobothrial process, and by the apical shape of the phallosome.

Trichadenotecnum lingens Yoshizawa and Lienhard, $\mathbf{n}$. sp.

(Figs 1B, 3)

http://zoobank.org/58786FC5-8180-455B-A20C7E8541606D50

Holotype. Male. THAILAND, Suphanburi, Pu Toei NP, Pinus merkusii forest, $14^{\circ} 58.4^{\prime} \mathrm{N} 99^{\circ} 26.017^{\prime} \mathrm{E}, 763 \mathrm{~m}$, Malaise trap, 8-15.viii.2008, Saunbua L. leg. T3144 (Tiger 46).

Description. Male (head and prothorax missing).

Thorax. Brown except for white membranous region and white longitudinal line in middle of mesoscutum; with white region on posterior region of each metascutum lobe.

Legs. Missing except for brown mid and hind coxae.

Forewing. As in Fig. 1B.

Terminalia. Epiproct (Fig. 3AB) with small anteromedian lobe dorsally covered with papillae. Paraproct (Fig. 3A) with tubercular trichobothrial process covered with denticles; with weak dorsal swelling at base of distal lobe; distal process slender. Hypandrium (Fig. 3C) with well-developed left process; median tongue elongated, apically broadened, posterointernal margin serrated; right corner with posterolateral projection. Phallosome (Fig. 3D) with broad and medially concave distal process, its posterolateral corners denticulate.

Measurements. BL unavailable (head and prothorax missing); FW 2.4; HW 1.9.
Female. Unknown.

Etymology. Named after the strongly extended hypandrial median tongue; lingens means licking in Latin (present participle of the verb lingere $=$ to lick).

Remarks. This species can be distinguished from all other species of the corniculum group by its unique, strongly extended hypandrial median tongue.

\section{Trichadenotecnum palmula Yoshizawa and Lienhard,} n. sp. (Figs 1C, 4)

http://zoobank.org/99B363E6-5EC5-4B6E-A15657DE220FFF36

Holotype. Male. THAILAND, Chanthaburi, Khao Khitchakut NP, Sala/Chang-sae waterfall, $12^{\circ} 49.33^{\prime} \mathrm{N}$ $102^{\circ} 9.4^{\prime} \mathrm{E}, 290 \mathrm{~m}$, Malaise trap, 6-13.xi.2008, Sutuida \& Charoenchai leg. T3977 (Tiger 1).

Description. Male. Head. Almost uniformly blackish brown including mouthparts, except for four white spots around ocellar field, pair of white patches on frons, and white dorsal region of postclypeus. Eyes black, IO/D 0.6; ocellar field black.

Thorax. Blackish brown except for white membranous region and white longitudinal line in middle of mesoscutum; metascutum with small white spot on posterior end of each scutum lobe.

Legs. Blackish brown, fore femur paler.

Forewing. As in Fig. 1C.

Terminalia. Epiproct lobe (Fig. 4AB) only weakly swelling, broadly covered with papillae. Paraproct (Fig. 4A) with keel-like trichobothrial process covered with denticles; dorsal swelling basal to distal lobe not obvious; distal process broad basally, gradually narrowing to pointed tip. Hypandrium (Fig. 4C) with small left process; with weakly sclerotized median projection left to median tongue; median tongue elongated, parallel-sided, distal margin diagonally truncated and serrated; right corner strongly expanded posteriorly. Phallosome (Fig. 4D) with pair of broadly separated, slender, and strongly curved distal processes.

Measurements. BL 2.0; FW 2.4; HW 1.8.

Female. Unknown.

Etymology. Named after the blade-like hypandrial median tongue; palmula (a noun in apposition) means an oar's blade in Latin.

Remarks. The elongated and parallel-sided hypandrial median tongue is unique to this species within the corniculum group.

\section{Trichadenotecnum affinifelix Yoshizawa and Lienhard, n. sp. \\ (Figs 1D, 5) \\ http://zoobank.org/46F45502-E565-4944-9356- 781B8F0701AF}

Holotype. Male. THAILAND, Chanthaburi, Khao Khitchakut NP, Khao Prabant peak/ $150 \mathrm{~m} \mathrm{~S}$ of forest base, $12^{\circ} 50.45^{\prime} \mathrm{N} 102^{\circ} 9.81^{\prime} \mathrm{E}, 875 \mathrm{~m}$, Malaise trap, 6-13.ii.2009, Suthida \& Charoenchai leg. T4035 (Tiger 3).

Description. Male. Head. Vertex white in ground color, with blackish brown vertical and orbital markings; frons white, with pair of pale brown bands at middle; dorsal region of postclypeus white; other head structures including mouthparts and antennae blackish brown. Eyes black, IO/D 0.7; ocellar field black. 
Thorax. Mostly blackish brown, mesoscutum with white longitudinal line in middle; metanotum pale in ground color, each scutum lobe with large brown marking; membranous region white.

Legs. Blackish brown, fore femur paler.

Forewing. As in Fig. 1D.

Terminalia. Epiproct (Fig. 5A) lobe strongly expanded anterodorsally (dorsal illustration not available, epiproct lost during dissection). Paraproct (Fig. 5A) with keel-like trichobothrial process covered with denticles; with conical dorsal projection posterior to trichobothrial field; distal process broad. Hypandrium (Fig. 5B) without left process; with pair of tubercular processes left to median tongue; median tongue broad, with serrated left distal margin; right corner with broad internal expansion. Phallosome (Fig. 5C) with pair of apically denticulate processes each bearing a small internal subapical process.

Measurements. BL 2.1; FW 2.6; HW 2.0.

Female. Unknown.

Etymology. This species is very similar to $T$. felix Thornton, 1961 (affinis means "related to" in Latin).

Remarks. This species resembles $T$. felix Thornton, 1961 in male genital structures but can be distinguished from the latter by the apical structure of the phallosome.

Trichadenotecnum separatum Yoshizawa and Lienhard, n. sp.

(Figs 1E, 6)

http://zoobank.org/E6F92D60-8A01-4CC2-8EDA-BFFF9A82E787

Holotype. Male. THAILAND, Suphanburi, PU Toei NP, Pinus merkusii forest, $14^{\circ} 58.4^{\prime} \mathrm{N}$ 99²6.017' E, 763m, Malaise trap, 24-31.vii.2008, Sanbua L. leg. T3140 (Tiger $\left.3^{\prime}\right)$.

Description. Male (head missing).

Thorax. Dark brown except for white membranous region and white longitudinal line in middle of mesoscutum.

Legs. Missing, except for dark brown coxae.

Forewing. As in Fig. 1E.

Terminalia. Epiproct (Fig. 6AB) flat, well expanded anteriorly, with weak swelling posteromedially. Paraproct (Fig. 6A) with small and acutely pointed trichobothrial process; trichobothria broadly separated into two groups; distal lobe with broad dorsal swelling basally; distal process slender. Hypandrium (Fig. 6C) with laterally expanded keel near distal end of left corner, its posterior margin serrated; with pair of processes left to base of median tongue, left one short and broad, slightly bilobed, with rugose surface, right one well-developed, reaching to middle of median tongue; median tongue broad, distally rounded, with weakly serrated posterointernal margin; right corner not strongly developed, about same height of left corner. Phallosome (Fig. 6D) with pair of apically bifurcated processes, dorsointernal part of each process denticulate.

Measurements. BL unavailable (head missing); FW 2.4; HW 1.8.

Female. Unknown.

Etymology. Named after the widely separated paraproctal trichobothria; separatus means separated in Latin.

Remarks. This species is similar to T. pycnacanthum (Li, 2002) in some aspects of the hypandrial structures but is distinguished from it by the shape of the epiproct and the broadly separated paraproctal trichobothrial fields.

\section{DISCUSSION}

All five species treated here are superficially very similar (Fig. 1) but show significant differences in male genital structures (Figs 2-6). Except for T. alfonsoi n.sp. their descriptions are based on a single male specimen. However, judging from the intraspecific variations observed in $T$. alfonsoi $\mathrm{n}$. sp. or in the previously known species of the corniculum group (Yoshizawa 2003; Yoshizawa et al. 2014), the variations observed between the males examined for this study far exceed the known intraspecific variability. Thus, describing new species based on a single specimen clearly appears justified.

To date, species of the corniculum group are recorded from the Oriental (China including Hong Kong, Malaysia, Singapore and Indonesia) and the eastern Palaearctic (Japan) regions. All species described here from Thailand share two morphological characters with the previously known Oriental species: thin lamellate hypandrial median tongue and apically bifurcated phallosome. Both characters are apparently apomorphic, because they are not observed in the sister group of the corniculum group, the longimucronatum species group, and are also very rarely observed in other species of the genus Trichadenotecnum. Based on these synapomorphies, the Oriental species of the corniculum group likely form a monophyletic group representing the sister group of the clade composed of the two Japanese species. The latter also share a unique apomorphic character: the trichobothrial process arises from the distal end of the trichobothrial field (Yoshizawa, 2003).

Within the Oriental clade, one monophyletic group composed of T. palmula n. sp., T. affinifelix n. sp., T. separatum n. sp., T. felix Thornton, 1961 (Hong Kong), T. imrum New and Thoronton, 1976 (Malaysia and Singapore), and T. cinnamonum Endang and New, 2014 (Malaysia and Indonesia) can be recognized, which is characterized by the presence of one or two tubercular processes left to the hypandrial median tongue, both apparently representing an apomorphic condition (never observed in other Trichadenotecnum). T. pycnacanthum (Li, 2002) (China) may also belong to this clade because this species shares two apomorphies with T. separatum n. sp.: presence of a keel on the hypandrial left corner and apically forked phallosomal processes. However, the hypandrial tubercular processes are not illustrated for T. pycnacanthum (Li, 2002). Some of the hypandrial structures of $T$. pycnacanthum are not clearly illustrated in the original description so that the examination of the type material of this species is needed to decide its phylogenetic placement. Among the species from Thailand, T. alfonsoi $\mathrm{n}$. sp. and T. lingens $\mathrm{n}$. sp. are characterized by the presence of a well-developed hypandrial left process. However, the hypandrial left process is widely observed throughout Trichadenotecnum, and a less developed left process can also be seen in T. palmula $\mathrm{n}$. sp. and T. imrum, both belonging to the clade with the tubercular hypandrial processes.

The TIGER material contains five species of the corniculum group, which far exceeds the previously known diversity of this group in other countries or regions: two species from Japan, two from China including Hong Kong, and two from Malaysia + Singapore + Indonesia. This strongly suggests that the diversity of the corniculum group is in reality much higher, especially in the Oriental region. The present results show the efficiency of the sampling conducted by 
the TIGER project and the great importance of this project for uncovering insect diversity in Thailand.

\section{ACKNOWLEDGMENTS}

We dedicate this paper to our colleague and friend, Alfonso Neri García Aldrete, in recognition of his outstanding contribution to the systematics of Psocoptera. We thank Michael Sharkey for entrusting the psocids collected in the course of the TIGER project to the Geneva Natural History Museum, and we are grateful to Thérèse Cuche, former technician at the Geneva Museum, for her tireless sorting and labeling of this huge collection. This study was partly supported by JSPS grants $19 \mathrm{H} 03278$ and 24570093 to KY.

\section{LITERATURE CITED}

Kentjonowati, E.S. and T.R. New. 2005. The genus Trichadenotecnum (Insecta: Psocoptera: Psocidae) in Sumatra, Indonesia, with description of thirteen new species. Records of the Australian Museum 57: 15-38.

Li, F. 2002. Psocoptera of China. Science Press, Beijing, $1976 \mathrm{pp}$.

New, T. R. and I.W.B. Thornton. 1976. Psocomorpha (Psocoptera) from the Malayan Peninsula. Oriental Insects 9: 375-418.

Thornton, I.W.B. 1961. The Trichadenotecnum group (Psocoptera: Psocidae) in Hong Kong, with descriptions of new species. Transactions of the Royal Entomological Society, London 113: 1-24.
Yoshizawa, K. 2003. Two new species that are likely to represent the most basal clade of the genus Trichadenotecnum. Entomological Science 6: 301-308.

Yoshizawa, K. and C. Lienhard. 2004. Systematics of Trichadenotecnum (Psocoptera: Psocidae) in Hong Kong. Publicaciones Especiales Instituto de Biología, UNAM (20): 121-149.

Yoshizawa, K. and C. Lienhard. 2015a. The alinguum group, a new species group of the genus Trichadenotecnum, with descriptions of two new species from Thailand (Psocodea: 'Psocoptera': Psocidae). Insecta Matsumurana, new series 71: 179-188.

Yoshizawa, K. and C. Lienhard. 2015b. Synonymy of Cryptopsocus Li with Trichadenotecnum Enderlein (Insecta: Psocodea: 'Psocoptera': Psocidae) and description of three new species. Zootaxa 3957: 480-488.

Yoshizawa, K., C. Lienhard, and A.B. Idris. 2014. Trichadenotecnum species from Peninsular Malaysia and Singapore (Insecta: Psocodea: 'Psocoptera': Psocidae). Zootaxa 3835: 469-500.

Yoshizawa, K., I. Yao, and C. Lienhard. 2016. Molecular phylogeny reveals genital convergences and reversals in the barklouse genus Trichadenotecnum (Insecta: Psocodea: 'Psocoptera': Psocidae). Molecular Phylogenetics and Evolution 94: 358-364.

Yoshizawa, K., K.P. Johnson, I. Yao, J.A. Casasola González, E. Bess, and A.N. García Aldrete. 2017. Multiple trans-Beringia dispersals of the barklouse genus Trichadenotecnum (Insecta: Psocodea: Psocidae). Biological Journal of the Linnean Society 121: 501-513.
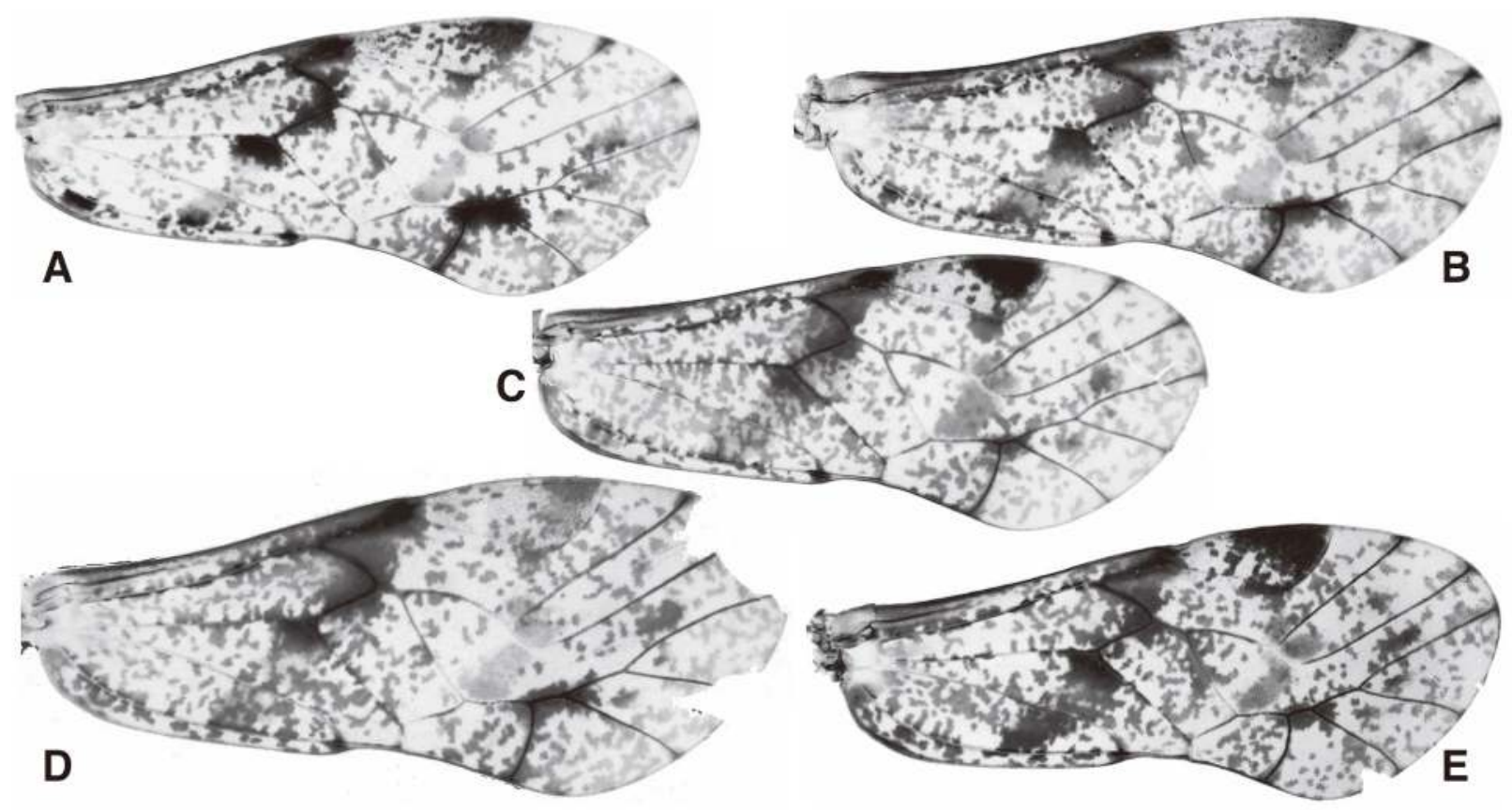

Figure 1. Male right forewing of the new species of the Trichadenotecnum corniculum group (holotypes). A. T. alfonsoi. B. T. lingens. C. T. palmula. D. T. affinifelix. E. T. separatum. 


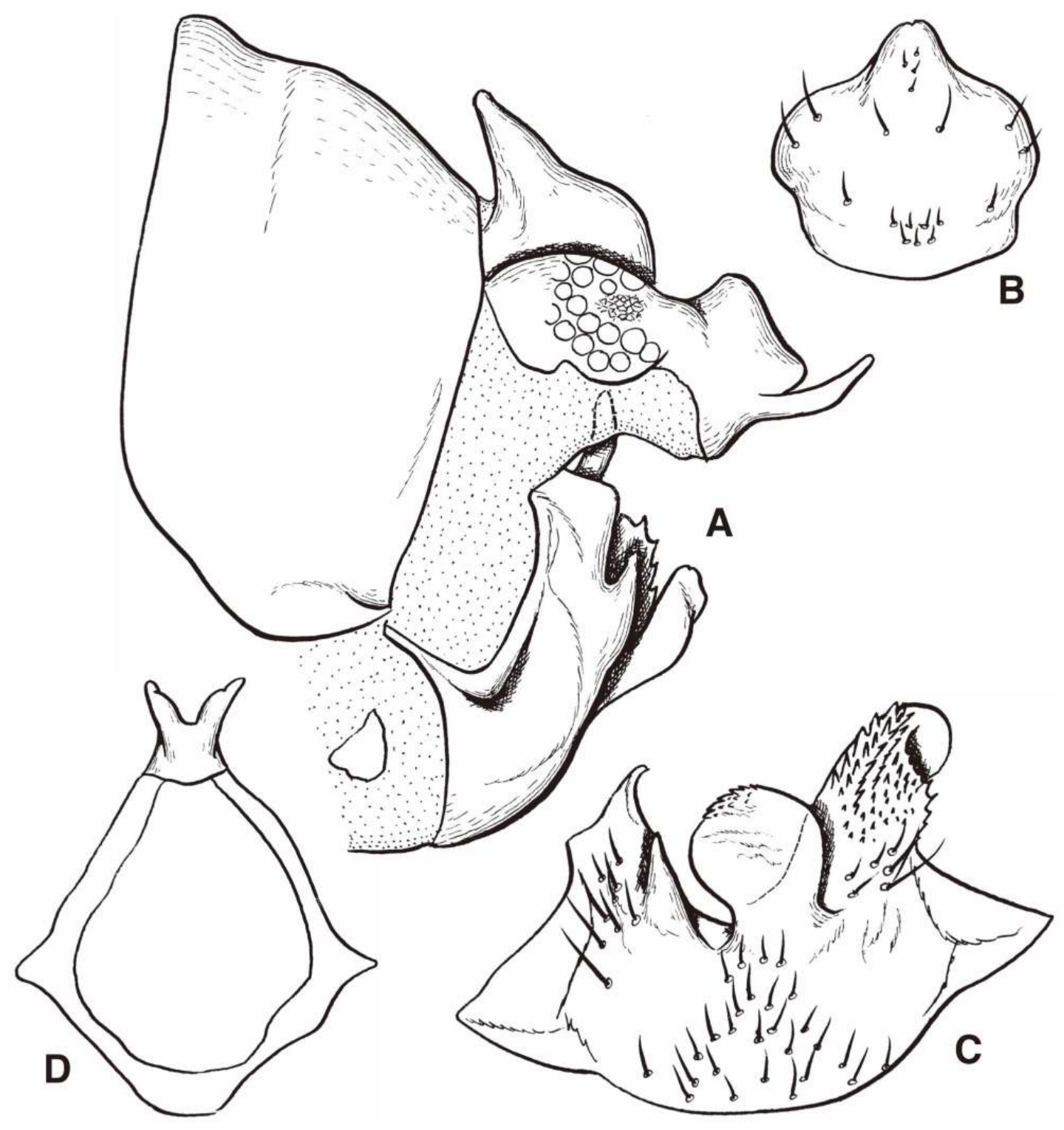

Figure 2. Male terminalia of Trichadenotecnum alfonsoi n. sp. (holotype). A. Terminalia, lateral view. B. Epiproct, dorsal view. C. Hypandrium, posteroventral view. D. Phallosome, ventral view. 


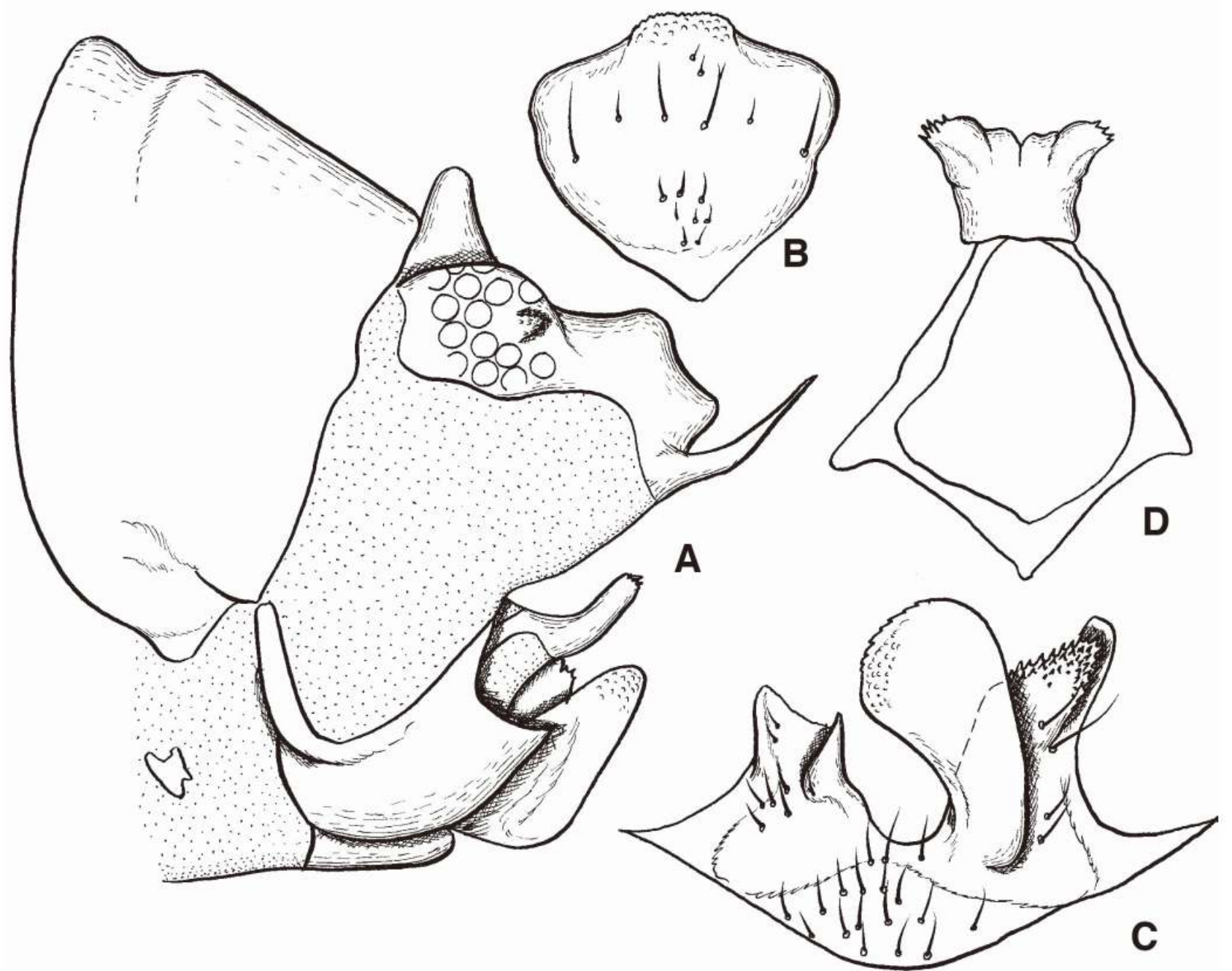

Figure 3. Male terminalia of Trichadenotecnum lingens $\mathrm{n}$. sp. (holotype). A. Terminalia, lateral view. B. Epiproct, dorsal view. C. Hypandrium, posteroventral view. D. Phallosome, ventral view. 


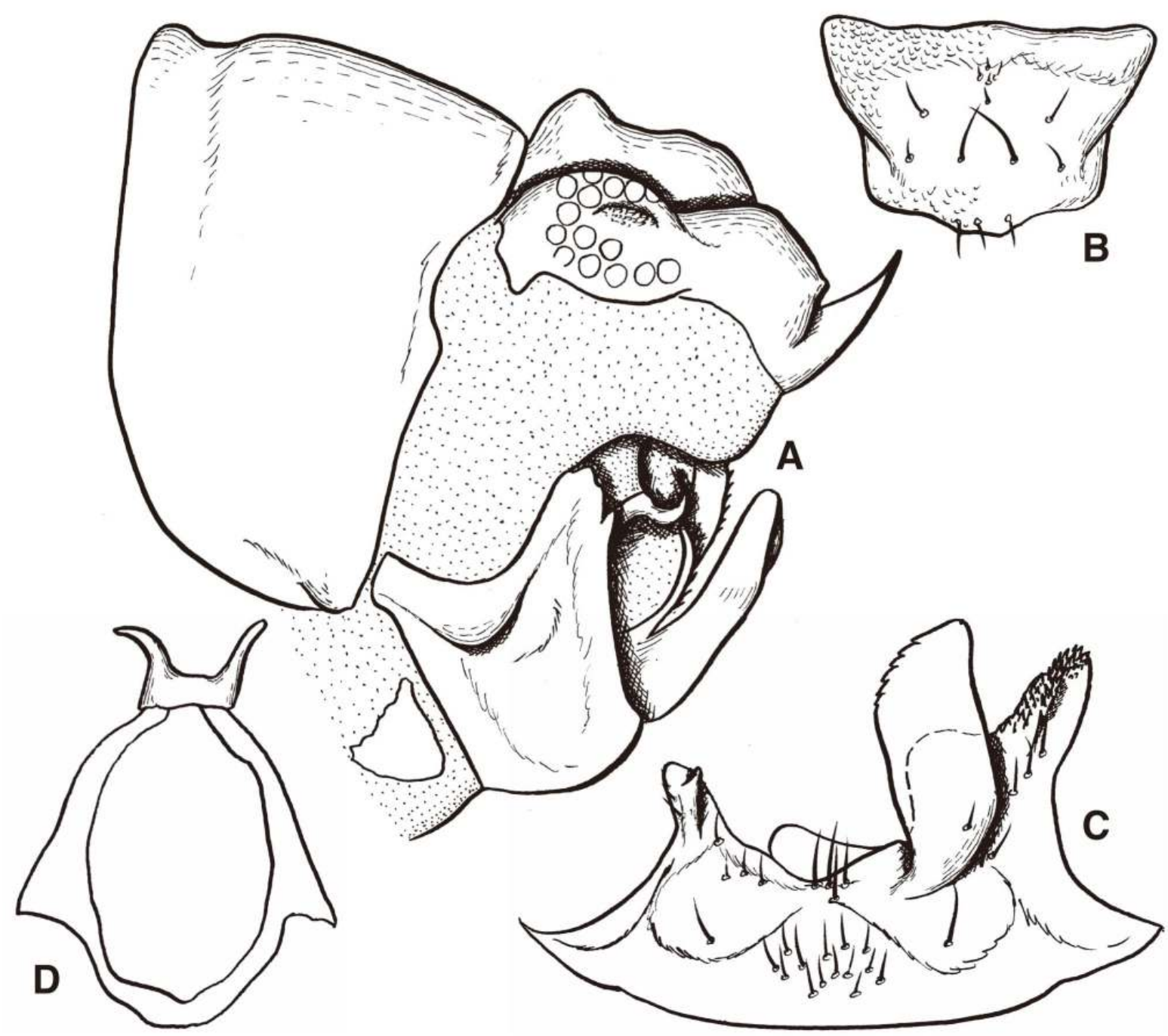

Figure 4. Male terminalia of Trichadenotecnum palmula $\mathrm{n}$. sp. (holotype). A. Terminalia, lateral view. B. Epiproct, dorsal view. C. Hypandrium, posteroventral view. D. Phallosome, ventral view. 


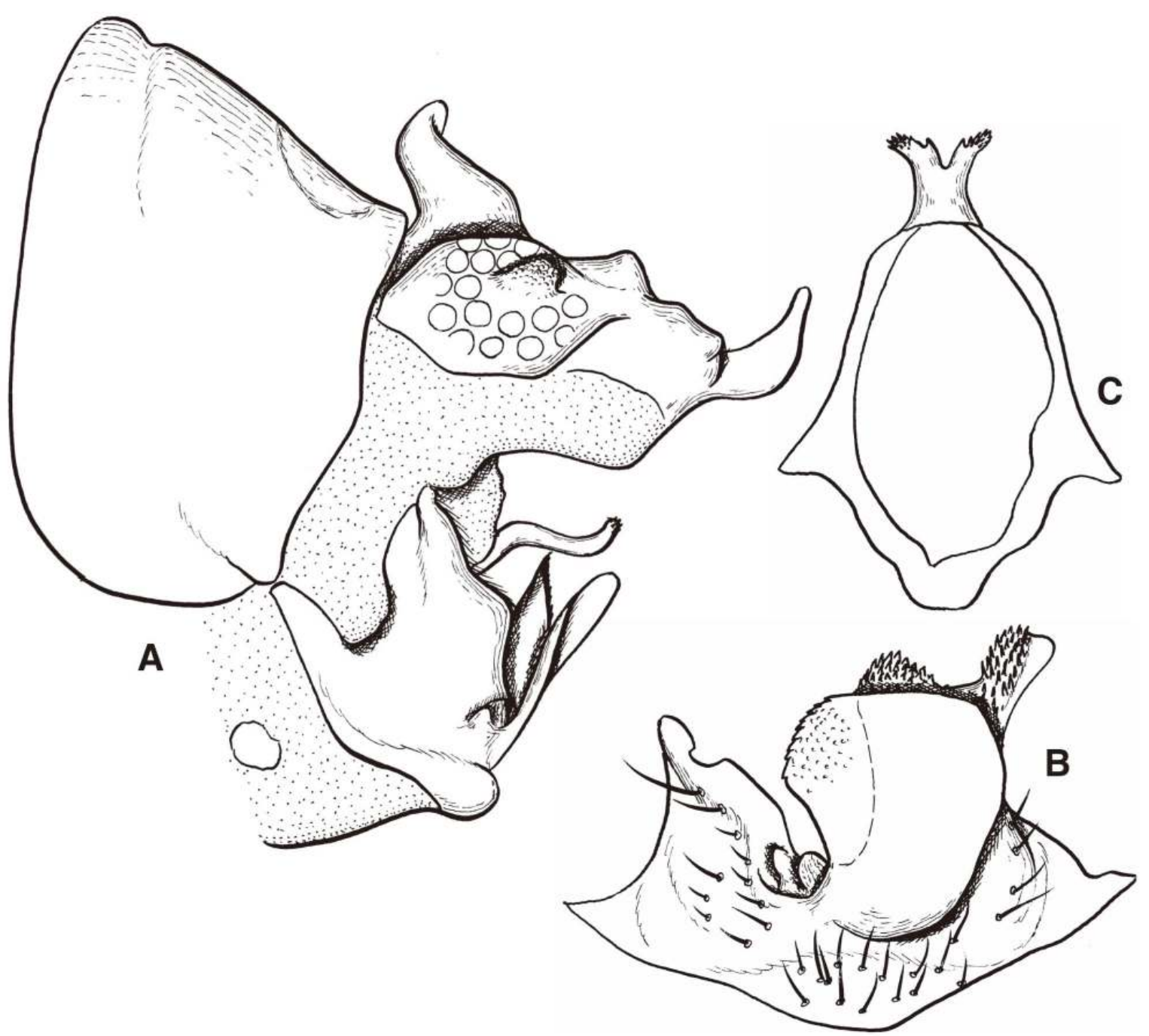

Figure 5. Male terminalia of Trichadenotecnum affinifelix $\mathrm{n}$. sp. (holotype). A. Terminalia, lateral view. B. Hypandrium, posteroventral view. C. Phallosome, ventral view. 


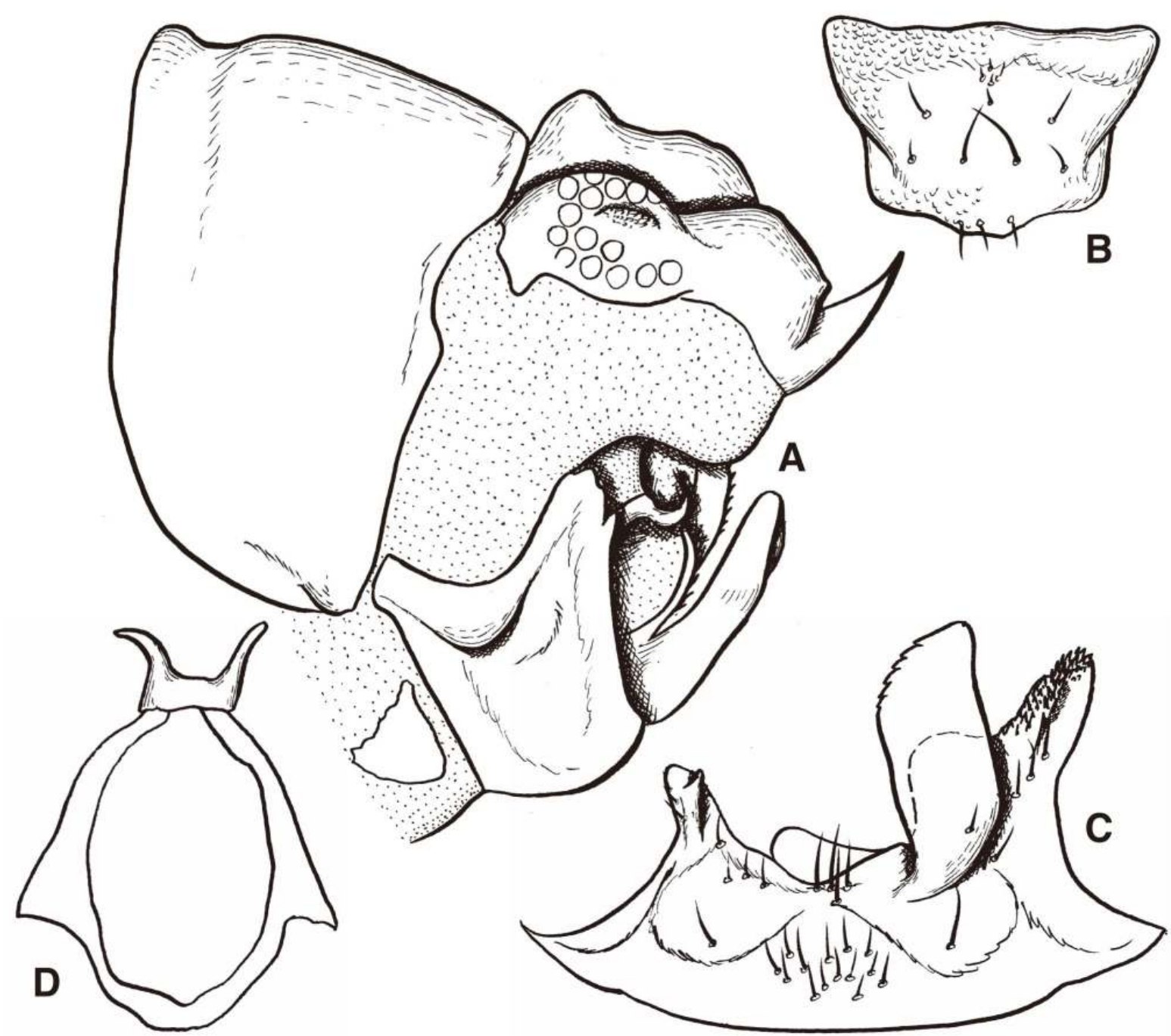

Figure 6. Male terminalia of Trichadenotecnum separatum n. sp. (holotype). A. Terminalia, lateral view. B. Epiproct, dorsal view. C. Hypandrium, posteroventral view. D. Phallosome, ventral view. 